
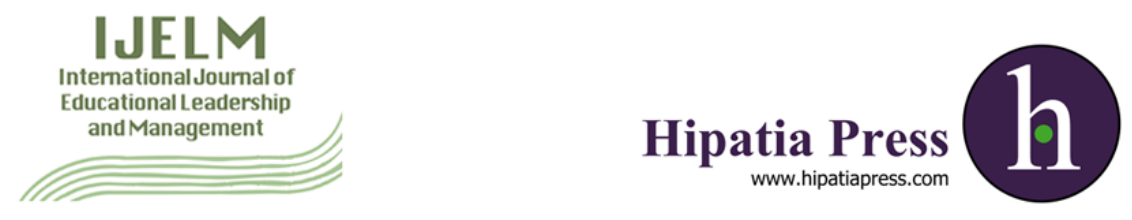

Instructions for authors, subscriptions and further details:

http://ijelm.hipatiapress.com

\title{
The Effect of Authentic Leadership on School Culture: A Structural Equation Model
}

\author{
Engin Karadag, $\mathrm{PhD}^{1}$ \\ Ozge Oztekin-Bayir, $\mathrm{PhD}^{2}$
}

1) Akdeniz University, TURKEY

2) Eskisehir Osmangazi University, TURKEY

Date of publication: January $16^{\text {th }}, 2017$

Edition period: January 2018-July 2018

To cite this article: Karadag, E. \& Oztekin-Bayir, O. (2018). The effect of authentic leadership on school culture: A structural equation model. IJELM, 6(1), 40-75. doi: 10.17853/ijelm.2018.2858

To link this article: http://dx.doi.org/10.17583/ijelm.2018.2858

PLEASE SCROLL DOWN FOR ARTICLE

The terms and conditions of use are related to the Open Journal System and to Creative Commons Attribution License (CC-BY). 


\section{The Effect of Authentic Leadership on School Culture: A Structural Equation Model $^{1}$}

Engin Karadag, $\mathrm{PhD}$ Akdeniz University
Ozge Oztekin-Bayir, PhD

Eskisehir Osmangazi University

\section{Abstract}

In the study, the effect of school principals' authentic leadership behaviors on teachers' perceptions of school culture was tested with the structural equation model. The study was carried out with the correlation research design. Authentic leadership behavior was taken as the independent variable, and school culture was taken as the dependent variable. The participants in the study were 256 teachers from 15 elementary schools. In the study, the research data were collected with the Authentic Leadership Scale (Walumbwa, Avolio, Gardner, Wernsing \& Peterson, 2008) and the Organizational Culture Scale (Karadağ, 2009). The Authentic Leadership Scale included the factors of (i) self-awareness, (ii) transparency in relations, (iii) balanced processing and (iv) internalized ethical viewpoint; as for the Organizational Culture Scale, it was made of such factors as (i) managerial and (ii) aim. In the study, in order to test the structural equation model formed theoretically, path analysis was conducted to investigate the appropriate models and to combine the measurement error in both latent and observed variables. The findings obtained demonstrated that the school principals' authentic leadership behaviors had positive effect on teachers' perceptions of school culture.

Keywords: Authentic leadership, School culture, Structural equation model.

\footnotetext{
${ }^{1}$ This work was supported by the GEBİP Award of the Turkish Academy of Sciences.
} 


\section{El Efecto del Liderazgo Auténtico en la Cultura Escolar: un Modelo de Ecuación Estructural}

Engin Karadag

Akdeniz University
Ozge Oztekin-Bayir

Eskisehir Osmangazi University

\section{Resumen}

En el estudio, se testeó el efecto del comportamiento del liderazgo auténtico de directores de centros escolares sobre las percepciones del profesorado de la cultura escolar. El estudio se llevó a cabo con el diseño de investigación de correlación. El liderazgo auténtico se tomó como variable independiente, y la cultura escolar se consideró como variable dependiente. Los participantes del estudio fueron 256 profesores de 15 escuelas primarias. En el estudio, los datos de investigación se recogieron con la Escala de Liderazgo Auténtico (Walumbwa, Avolio, Gardner, Wernsing \& Peterson, 2008) y la Escala de Cultura Organizacional (Karadağ, 2009). El Liderazgo Auténtico incluyó los factores de (i) propia conciencia, (ii) transparencia en relaciones, (iii) procesamiento equilibrado y (iv) punto de vista ético internalizado; en relación a la Escala de Cultura Organizacional, se realizó con factores de (i) gestión y (ii) objetivo. En el estudio, para testear el modelo de ecuación estructural teóricamente elaborado, se realizó un análisis de trayectoria para investigar los modelos apropiados y combinar las medidas de error tanto en las variables latentes como las observadas. Los resultados obtenidos demuestran que los comportamientos de liderazgo auténtico de los directores tenían efectos positivos en las percepciones del profesorado sobre cultura escolar.

Palabras clave: liderazgo auténtico, cultura escolar, modelo de ecuación estructural. 

he concept of leadership that occurred as the human being started to live in communities is one of the oldest issues that has always drawn the attention of researchers. Today, it has become widespread in organizations and now plays an important role in helping organizations achieve their goals. Therefore, the number of studies investigating the effect of leadership on organizational outcomes is gradually increasing. Leadership, a concept constantly discussed and investigated, is generally a process of guiding and organizing people (Kotter, 1990). Examined from different points of view starting from the beginning of the $20^{\text {th }}$ century, leadership was analyzed with such concepts as power and authority, innate characteristics (Stogdill, 1948), group dynamic, interaction with group members (Whyte, 1943), being relationship-oriented or task-oriented (Blake \& Mouton, 1964; Fiedler, 1967; Reddin, 1970), being authoritative or democratic (McGregor, 1960) and effectiveness. Thus, leadership led to a variety of leadership approaches and theories (Karadağ, 2009). In addition, the process of transition from the idea of administration to leadership and from instructional leadership to transformative leadership not only brought about new expectations but also caused organizations to seek for renovations to meet their changing needs (Senge, 1990). With ongoing research on leadership, today, new leadership theories appropriate to current conditions constitute the subject of today's discussions, and the theory of authentic leadership has recently been a popular theory of leadership.

Authentic leadership, which is based on self-consciousness and selfawareness, is defined as a process and behavior pattern, which is built on positive psychological competencies and at the same time contributing to the development of these competencies; being formed on transparency, openness and trust basis; guiding meaningful goals and focusing on the development of the followers (Gardner, Avolio, Luthans, May \& Walumbwa, 2005; Luthans \& Avolio, 2003; Walumbwa et al., 2008). Authentic leadership, which is considered as one of the positive leadership styles, contributes to the formation of a positive organizational culture as well. The concept of organizational culture, which is focused on the performances, managerial efficiency and organizational behaviors of the organizations (Alvesson, 1993; Hofstede, 1998), also forms the basis of school culture concept.

School culture is a social structure that is closely related to leadership in terms of revealing educational institutions' meaning, character, internal 
dynamics and relationships with their surroundings (Gruenert, 2005; Yalçın \& Karadağ, 2013). School principal plays a key role in shaping school culture and sustaining it by creating a warm learning environment (Deal \& Peterson, 1999; Harris, 2002; Hoy \& Miskel, 2012). The researches indicate that schools are the organizations that both produce and transfer the culture (Çelik, 2002); and school principals are the best representatives of school culture (Şişman, 2002). Although there are many researches that address the relationship between the leadership and school culture (Alig-Mielcarek, 2003; Harris, 2002; Kouzes ve Posner, 2002,; Şahin, 2004), the literature does not have enough work describing the impact of authentic leadership on school culture. For this reason, authentic leadership, which has positive effects on organizational commitment by creating a sense of mutual trust, is thought to be effective on the school culture, which similarly enhances motivation, increases efficiency and creates commitment by defining basic values.

\section{Authentic Leadership}

In recent years, as a new concept in literature on leadership, authentic leadership has been examined within the scope of modern leadership theories (Chan, Hannah \& Gardner, 2005). Although authentic leadership initially occurred as a component related to transformative leadership, it was not identified clearly at all (Bass, 1990; Bass \& Steidlmeier, 1999). Therefore, in order to better understand the concept of authentic leadership, it is primarily necessary to focus on what the word of authenticity means in different contexts. Authenticity, which has recently been a frequent subject matter in different disciplines, originated as 'know thyself' in ancient Greek philosophy. The origin of the concept is known to have originated from a Greek word, authenteo (having all the power), and it could be adapted to organizational environments based on one's own experiences, beliefs and truths. In addition, the concept of authenticity has a number of different meanings such as reflecting the life style, demonstrating the real feelings and having ethical responsibility for values (Baumaster, 1987; Goldman \& Kernis, 2002; Harter, 2002). According to Kernis and Goldman (2006), the concept of authenticity is made up of four components: (i) awareness relying on one's own thoughts, feelings and values-, (ii)unbiased processing- acknowledging positive and negative aspects without any 
previous prejudice-, (iii)behavior- pleasing others, being awarded or acting on one's own ethical values rather than trying to avoid punishment- and (iv)relational orientation -being honest and frank in intimate relationships. The concept of authenticity, made up of several components, constitutes a theoretical basis for the authentic leadership approach.

Taking authenticity into consideration within the framework of organization, Rome and Rome (1967, cited in Gardner, Cogliser, Kelly \& Dickens, 2011) stated that organizations can become authentic to the extent they become aware of uncertainties, accept the mistakes and recognize their responsibilities, power and choices together with the current leadership approaches. In another study, organization was considered with such concepts as " $(i)$ authenticity- discovering the concept of self by establishing meaningful relationships within the organizational structures-, (ii) intentionality- visionary leadership which takes its energy from the good intentions of organization members who do their best to create a vision for future-, (iii) spirituality- rediscovering the spiritual aspect of people- and (iv) being sensitive to the feelings and needs of others (Bhindi \& Duignan, 1997).

Begley (2001) reported an alternative view that authentic leadership could be used as a metaphor in the field of educational administration and claimed that authentic leadership has aspects similar to effective and ethical leadership. Different from previous studies, George (2003), focusing on the personal development of authentic leaders, pointed out that these individuals demonstrate a constant effort to develop themselves and that authentic leadership had five dimensions: $(i)$ being ambitious to achieve the goals, (ii) putting forward the values, (iii) guiding with feelings, (iv) establishing permanent relations and $(v)$ self-discipline (George \& Sims, 2007). According to these dimensions, (i) being ambitious to achieve the goals refers to the fact that authentic leaders first know themselves and their ambition and then try to find ways to achieve their goals; (ii) putting forward the values refers to the fact that leaders, even under pressure, demonstrate behaviors in line with the values; (iii) guiding with feelings refers to the fact that leaders do their job willingly, empathize with employees and take the courage to make challenging decisions; (iv) establishing permanent relations refers to the fact that employees establish relationships with the leader based on confidence and become loyal to the organization; and (v) self-discipline refers to the fact that leaders put 
forward high standards for themselves and expect others to show the same enthusiasm in doing the job and that authentic leaders undertake the whole responsibility rather than charging others with the mistakes made.

Studies conducted in recent years have not only claimed that authentic leadership is a type of constructive leadership which has occurred in line with the current increasing need for effective leadership and which is more than traditional leadership styles since followers are effectd with ethical and specific behaviors but also constituted the theoretical foundations of this approach with such concepts as positive organizational behavior, transformative leadership and ethical viewpoint (Avolio, 1999; Avolio \& Gardner, 2005; Luthans, 2003; Luthans \& Avolio, 2003). Behaviors considered to be constructive organizational behaviors formed the substructure of the concept of psychological capital in future studies (Luthans, Avolio, Avey \& Norman, 2007).

It is reported in related literature that authentic leaders consciously think hard about thinking processes, become aware of others' values, strong aspects and knowledge, demonstrate optimistic attitudes for future and have a character that gives importance to ethical values (Avolio, Luthans \& Walumbwa, 2004) and that they are reliable, well-behaved, frank, highly dedicated and respectable individuals (Avolio, Gardner, Walumbwa, Luthans \& May, 2004). However, when these definitions are taken into consideration, it is seen that although they reflect such basic components as self-awareness, self-regulation and ethical viewpoint, there is no clear-cut discrimination among authentic leadership, psychological capital and transformative leadership, which resulted in putting forward better definitions (Avolio \& Gardner, 2005; Gardner, Avolio, Luthans, May \& Walumbwa, 2005). Subsequent studies were comprehensive, and a fourcomponent authentic leadership approach which considered the dimensions suggested by Kernis and Goldman (2006) and which was adopted in the present study was obtained (Walumbwa, Avolio, Gardner, Wernsing and Peterson, 2008). These four dimensions were as follows:

(i) Self-awareness: It refers to the leader's awareness of how he or she perceivesthe world and how this process effects his or her self-perception in time. When individuals are aware of themselves, this helps them discover their strong and weak sides. Taking a trip in their inner worlds, authentic leaders not only raise their awareness of how they effect their followers but also they express themselves according to their own values and thoughts. In 
addition, the most typical characteristics of authentic leaders include having a reliable and well-behaved personality (Avolio et al., 2004). As authentic leaders think they have the full power, the most important capitals of authentic leaders are their own experiences and values. Making decisions in line with their own values play a role in taking the responsibility for their mistakes.

(ii) Transparency in relations: This refers to leaders' being direct and confident in their relationships. Transparency in relations which is achieved when authentic leaders transfer their own thoughts and beliefs directly and which thus requires authentic consciousness (Gardner et al., 2005) helps followers recognizes authentic leaders' actual consciousness. In this way, authentic leaders try to create a sense of confidence by expressing themselves in a manner appropriate to the conditions in the environment (Tabak, Polat \& Türköz, 2012).

(iii) Balanced Processing: In this component, leaders evaluate all the related information objectively before making a decision. Also, according to this component, leaders objectively acknowledge their own strong and weak sides (Kernis \& Goldman, 2006). Authentic leaders want other individuals to report their views about their own attitudes and respect others' related views (Gardner et al., 2005).

(iv) Internalized ethical viewpoint: In studies carried out on authentic leadership, it was claimed that authentic leaders are highly well-behaved (Avolio \& Gardner, 2005; Gardner et al., 2005; Kernis, 2003; Kernis \& Goldman, 2006; Luthans \& Avolio, 2003). In addition, this component includes the fact that leaders demonstrate attitudes consistent with their beliefs and values and that they make their decisions based on high levels of ethical standards.

In this respect, recent studies on leadership have mostly examined the relationship between authentic leadership and several variables. The findings obtained revealed that authentic leadership had a positive relationship with such variables as identification with the school principal (Walumbwa, Wang, Wang, Schaubroeck \& Avolio, 2010), personal identity (Wong, Spence Laschinger \& Cummings, 2010), confidence in the leader (Clap-Smith, Vogelgesang \& Avey, 2009; Wong et al., 2010), job satisfaction (Jensen \& Luthans, 2006; Walumbwa et al., 2008), organizational dedication (Jensen \& Luthans, 2006; Walumbwa et al, 2008), work happiness (Jensen \& Luthans, 2006), employee 
commitment(Jensen \& Luthans, 2006; Walumbwa et al., 2008), job performance (Walumbwa et al., 2008) and a negative relationship with the variable of emotional fatigue (Wong \& Cumming, 2009). Therefore, authentic leadership influential on organizations could also be thought to have effect on school culture including the values, beliefs, norms and traditions in schools which are regarded as educational organizations. For this reason, school culture was another variable the present study focused on

\section{School Culture}

It is believed that schools develop their own identity and culture in time (Şişman, 2007). School culture, which forms the basic personality of a school, is generally defined as the common values, beliefs, symbols and meanings shared by school members (Çelik, 2000; Şişman, 2007). Moreover, the school culture, which is formed by the norms, traditions, myths, interactions, rituals, and events (Karpicke \& Murphy, 1996; Lambert, 1988), also helps school principal, teachers and students to make sense of their lives and the world they are interacting. Similarly Deal and Peterson (1999), argue that culture is a set of value interlocking the people who work in an organization to each other; it affects and shapes the feelings and thoughts of the stakeholders in the school. In this respect, school culture is an effective way of organizational engagement and coordination among members (Schein, 1992; Sergiovanni, 2006). In addition, school culture creates a cooperation-based environment that helps establish healthy interaction (Peterson \& Brietzke, 1994). School culture is both a product as information and a constantly renewed and adopted process (Bolman \& Deal, 2003). In a more general sense, school culture is regarded as norms which are influential on instructional activities and which are put forward by school principals, teachers and parents to solve the current problems at school (Peterson \& Deal, 1999). Similarly, Stolp and Smith (1995) define school culture as a whole of values, norms and beliefs shared by school members. School culture is important since it effects not only the educational activities but also the productivity of structural changes for improvement at school (Hamilton \& Richardson, 1995; Keedy \& Achilles, 1997). In addition, school culture is also important in terms of defining basic values, creating commitment, clarifying the focus of daily behaviors, 
drawing attention to the topic of what is important and valued, enhancing motivation and increasing school activity (Peterson \& Deal, 2009).

School culture, which can be considered as a prerequisite of effective school, has basic factors such as (i) shared values, (ii) humor, (iii) storytelling, (iv) communication network, (v) rituals and ceremonies, and (vi) relationships between colleagues (Pawlas, 1997); it is well-known that school culture is closely related to the concepts such as organizational structure, decision-making, communication, and change (Lunenburg \& Ornstein, 2011). The review of the researches showed that positive school culture is related to the concepts such as organizational success and effectiveness (Kotter \& Heskett, 1992); student achievement (Demirtaş, 2010; Karadağ, Kılıçoğlu ve Yılmaz, 2014), organizational commitment and job satisfaction (Canizo, 2002; Hatchett, 2010); cooperation (HornHasley, 2007; Lima, 2006); organizational trust and organizational citizenship (Arl1, 2011); organizational cynicism (Şirin, 2011); work motivation (Tanrıversi, 2007); bureaucratization (Yüksel, 2009); mental health (Yau Ho, 2010); and empathy (Barr, 2011). As can be seen, school culture, which was analyzed with many different variables, brings awareness to school managers about the changes and innovations that will be performed at school, in addition to preparing the ground to establish a warm learning environment.

When the related literature is reviewed, it is seen that school culture, which has an important role in effective functioning at school in its multidimensional structure, is a social variable which has a close relationship with the leadership behaviors of the school principal (Yalçın \& Karadağ, 2013). For this reason, it is necessary for school principals to be aware of the school culture they belong to (Schein, 1992). School principals work with sharers at school to create a common vision by shaping the school culture in time (Çelikten, 2003).

Although the studies featuring the determination of the factors that form school culture were kept in the background of the discussions mentioned above, they gained particular importance nowadays. It can be said that there are different factors affecting the formation of school culture. School principals, in other words leaders, are positioned as the most important determinant of this formation process. While the basic values and beliefs create the infrastructure of organizational culture, leaders are the symbols of them; the models or agents that reflect them through their characters. 
Katz and Kahn (1978), who are the developers of system theory, have expressed this fact by defining the function of organizational leader as creating an excess of the domain by motivating the members of the organization to perform beyond a mechanical adaptation of the routine orientation of the organization. Up until now, leadership has been investigated by a number of researchers in terms of its effect on school culture and other related applications (Lucas, 2001; Miles, 2002; Schooley, 2005). Despite these studies, in literature, there is not much research examining the effect of authentic leadership on school culture. As can be understood from the theoretical framework regarding the concepts, the authentic leadership behaviors of school principals are expected to have positive effect on school culture. In line with the current needs and expectations, the hypotheses put forward in the present study were as follows:

$\mathbf{H}_{\mathbf{1}}$ There is a positive relationship between school principals' authentic leadership behaviors and teachers' perceptions of school culture.

$\mathbf{H}_{\mathbf{2}}$ School principals' authentic leadership behaviors have positive effect on teachers' perceptions of school culture.

\section{Method}

\section{Design}

In this study, a model was developed based on the authentic leadership behaviors of elementary school principals: effect of authentic leadership on school culture. In this respect, the study was carried out with the causal design. Causal design is a research design that examines the current causeeffect relationships between certain variables (Karadağ, 2009). A number of studies in related literature (Avolio \& Bass, 2002; Schein, 1985; Şahin, 2011; Trice \& Beyer, 1993; Yalçın \& Karadağ, 2013) revealed a relationship between leadership and school culture, which constituted the variables in the present study. In this study designed based on the thought that the relationship revealed in these studies was a cause-effect relationship, authentic leadership was taken as the independent variable, and school culture was taken as the dependent variable. The requirements 
for the existence of a cause-effect relationship between these two variables were as follows (Neuman, 2007):

(i) Order of time: According to this requirement, the cause happens before the result, and this situation determines the direction of causality. In order to determine the order of time based on the literature regarding the research variables, the results of studies reporting that leadership behaviors constitute school culture (Bolton, 2011; Herndon, 2007; Lahtero \& Rsiku, 2012; Mees, 2008; Turan \& Bektaş, 2013; Troutman, 2012; Miles, 2002; Veiseh, Mohammadi, Pirzadian \& Sharafi, 2014) required authentic leadership to be taken as the variable of cause.

(ii) Correlation: According to this requirement, at least two phenomena occur or act together in harmony. Although there are various methods to determine the correlations between variables, correlation coefficients were used to for the correlations between the variables in this study.

(iii) Eliminating the alternatives: This requirement refers to the fact that the result obtained/to be obtained in the study depends on the causal variable not on another thing. This situation is also known as being real since an apparently causal relationship that depends on an unrecognized cause is called fake relationship. As it is impossible to observe the alternatives in the study, this situation can only be demonstrated indirectly and it is not possible to eliminate all the alternatives. For this reason, in the present study, the structural equation model formed to eliminate the alternatives was checked with the software program of LISREL.

\section{Participants}

The universe of the research consists of 71 primary school teachers, who are working in 1702 primary schools located at the center of a big city, in Central Anatolia region. While defining the sample of the study, the primary schools included in the universe were categorized by triple layered sampling according to the socio-economic structure of the area where they are located (high-medium-low) and 256 primary school teachers who are working in the selected 15 primary schools have participated in the study. During the study, data collection tools were applied to the teachers by the researches after providing necessary explanations; faulty data collection tools were immediately intervened. While calculating the representation power of the sample, confidence interval was accepted as 0.01, and error 
margin was taken as 0.05 . As a result of the computations, considering $5 \%$ confidence interval and 5\% error margin, the minimum sample size that represent the universe of 1702 units was found to be 234 . The participants of the study were 256 teachers from 15 different elementary schools. Of all the participants, 157 of them were female $(62.3 \%)$, and 96 of them were male $(37.5 \%)$. The average age for the participants was $38(S S=8.5)$, and they had an average teaching experience of 15 years $(S S=8.7)$.

\section{Data Collection Measures}

In the study, the research data were collected with two scales. One of the two scales was the Authentic Leadership Scale applied to determine the teachers' perceptions of the authentic leadership behaviors demonstrated by the school principals, and the other was the Organizational Culture Scale used to reveal the teachers' perceptions of school culture.

\section{Authentic Leadership Scale}

This scale was developed by Walumbwa, Avolio, Gardner, Wernsing \& Peterson (2008) to determine the authentic leadership behaviors of individuals. The scale was a five-point Likert-type scale made up of four factors [( $i)$ self-awareness, (ii) transparency in relations, (iii) balanced processing and (iv)internalized ethical viewpoint] and 16 items in total. Within the scope of the study, for the purpose of determining the construct validity of the scale adapted into Turkish, confirmatory factor analysis was conducted with the maximum probability technique. Among the fit indices regarding the confirmatory factor analysis of the Turkish version of the scale, the Chi-square $\left(\chi^{2}\right)$ value and the statistical significance levels were determined $\left[\chi^{2}=292.14, d f=100\right]$. Depending on the degree of freedom, the low Chi-square $\left(\chi^{2}\right)$ value $\left[\chi^{2} / d=2.92\right]$ demonstrated that the suggested construct was appropriate to the data collected. In addition, the other goodness of fit indices regarding the construct [RMSEA $=.08, \mathrm{CFI}=.94$, $\mathrm{NFI}=.91, \mathrm{AGFI}=.83]$ revealed that the suggested construct was appropriate to the scale. It was seen that the variables measured regarding the four factors that formed the scale were under the factors found in the original scale. In addition, the standardized coefficients which were obtained via the confirmatory factor analysis and which demonstrated the relationship 
between the factors and the items ranged from 0.41 to 0.92 . Consequently, the Authentic Leadership Scale included a total of 16 five-point Likert-type items and four factors such as (i) self-awareness, (ii) transparency in relations, (iii) balanced processing and (iv) internalized ethical viewpoint.

(i) Self-awareness: It refers to leaders' awareness of how they give meaning to their world and of how this process effects their perceptions in time.

Sample Items:

(1) My school principle seeks feedback to improve interactions with others.

(2) My school accurately describes how others view his or her capabilities.

(ii) Transparency in relations: It refers to the clear-cut and direct relationships established by leaders.

Sample Items:

(1) My school principle says exactly what he or she means.

(2) My school admits mistakes when they are made.

(iii) Balanced processing: According to this factor, leaders make a decision by objectively evaluating all the information about the situation in advance.

Sample Items:

(1) My school principle solicits views that challenge his or her deeply held positions.

(2) My school principle analyzes relevant data before coming to a decision.

(iv) Internalized ethical viewpoint: According to this factor, leaders demonstrate behavior in consistent with their beliefs and values and make decisions based on the upper-level ethical behavior standards.

Sample Items:

(1) My school principle makes decisions bades on high standards of ethical conduct. 
My school principle demonstrates beliefs that are consistent with actions.

\section{Organizational Culture Scale}

This scale was developed by Karadağ (2009) to determine the culture levels of schools based on teachers' perceptions. This was a five-point Likert-type scale made up of eight items and four factors. Within the scope of the study, in order to re-determine the construct validity of the scale, the confirmatory factor analysis was conducted with the maximum likelihood technique. Among the goodness of fit indices regarding the confirmatory factor analysis, the Chi-square value $\left(\chi^{2}\right)$ and the statistical significance levels were determined $\left[\chi^{2}=129.60, d f=16\right]$. Depending on the degree of freedom, low Chi-square $\left(\chi^{2}\right)$ value $\left[\chi^{2} / d f=8.1\right]$ demonstrated that the suggested construct was not appropriate to the data collected. In addition, the goodness of fit indices for the construct [RMSEA $=.16, \mathrm{CFI}=.89, \mathrm{NFI}=.88$, $\mathrm{AGFI}=$.74] revealed that the data collected were not appropriate to the construct suggested for the scale. According to this result, the values obtained within the scope of standard fit values demonstrated that the fourfactor construct was not confirmed. For this reason, the exploratory factor analysis revealed that there were two factors with an eigenvalue higher than (i) managerial and (ii) aim.

(i) Managerial:A higher score to be obtained regarding this dimension demonstrates that the leadership and leadership styles of principal(s) of the organization have a well-structured system in the processes of decision making, formal and informal communication within the organization, superior-subordinate relationships and the power and responsibilities.

Sample Items:

(1) Teachers are sharers of the decision-making mechanism of the school.

(2) The school administration supports the job done by teachers.

(ii) Aim: A higher score to be obtained regarding this dimension is an indicator of future situations desired by the organization workers.

Sample Items: 
(1) Teachers in our school volunteer to do extra job for the success of the school.

(2) Teachers in our school give as much importance to the preparation of students for life as to instructional activities.

The Cronbach Alpha coefficients calculated to determine the measurement reliabilities of the authentic leadership scale and the school culture scale were, as presented in Table 1, found to range between .80 and .96 .

Table 1. Number of Items and Reliability Coefficients of the Authentic Leadership Scale and School Culture Scale

\begin{tabular}{lll}
\hline Scale & Number of Items & Alpha \\
\hline Authentic Leadership Scale & 16 & .96 \\
\hline 1-Transparency in Relations & 5 & .83 \\
2-Internalized Ethical Viewpoint & 4 & .88 \\
3-Balanced Processing & 3 & .89 \\
4-Self-Awareness & 4 & .91 \\
\hline Organizational Culture Scale & 8 & .92 \\
\hline 1-Managerial & 4 & .86 \\
2-Aim & 4 & .80 \\
\hline
\end{tabular}

\section{Procedure}

The basic purpose of the present study was, with the use of the structural equation model, to test the hypothesis that elementary school principals' authentic leadership behaviors effect teachers' perceptions of school culture. As the model was formed with theoretical concepts and structures which were not possible to observe or measure directly, the structural equation model was used. The reason is that the structural equation model, which tries to explain the variables in the theoretical structure with certain indicators, reveals and formulizes the relationships that occur in a social and behavioral process thought to randomly function between latent variables. In the study, the structural equation model was used to determine the cause-effect relationships between authentic leadership and school 
culture. Each equation in the model represents the random link between latent variables rather than only an apparent association. Thus, the structural equation model aims at testing whether the data collected regarding an independent theoretical model (Barrett, 2007; Hooper, Coughlan \& Mullen, 2008; Hoyle \& Panter, 1995; Karadağ, 2009). The statistical methodology in the study included the following phases:

\section{Linear relationships}

In this phase, for the purpose of determining the relationships between authentic leadership and school culture, Pearson Correlation Analysis was conducted. In addition, Multiple Regression Analysis was used to determine to what extent authentic leadership predicts school culture.

\section{Establishment of the Theoretical Model}

In this phase, the theoretical model constituting the basis of the study was formed: a structural equation model demonstrating the effects of the authentic leadership behaviors of school principals on school culture was established (see Figure 1). The theoretical model was made up of three parts: two measurement components and one structural equation component. The measurement components were as follows: $(a)$ authentic leadership - the external variable of the model - made up of four observed variables [( $i$ ) self-awareness, (ii) transparency in relations, (iii) balanced processing and (iv) internalized ethical viewpoint]; (b) school culture - the internal variable of the model -made up of two observed variables $[(i)$ managerial and (ii) aim]. As for the structural equation model, it theoretically formulizes the relationships between latent variables: It was assumed that authentic leadership had direct effect on conscious school culture. In the model, the observed variables were represented with a rectangle; the latent variables were represented with oval boxes; and the factor loadings of the observed variables on the latent variables and the effect of the external variable on the internal variable were represented with linear lines. In addition, each observed variable also included a mistake. 


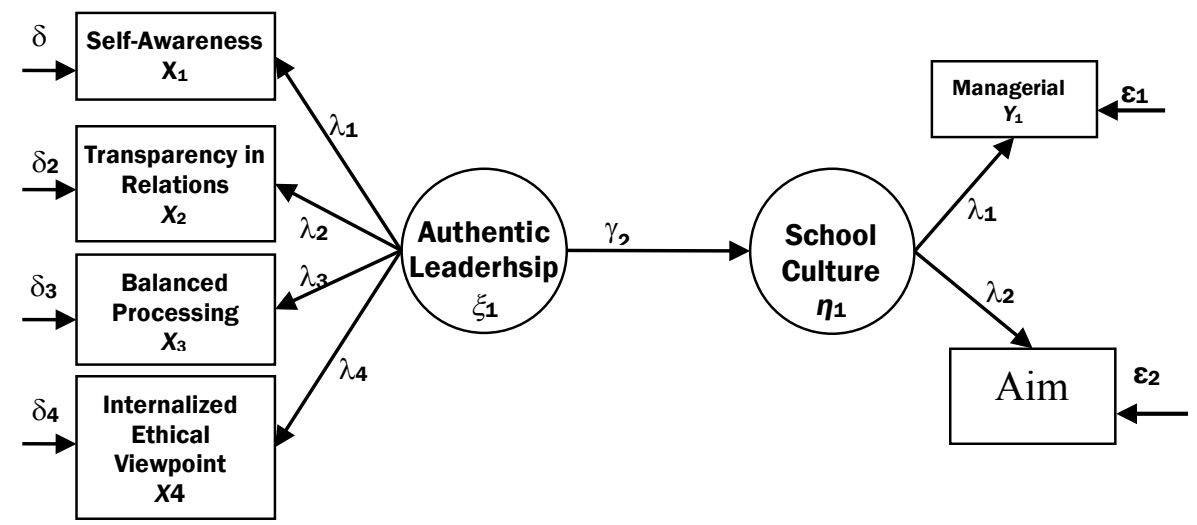

Figure 1. The Structural Equation Model for Authentic Leadership and School Culture

\section{Testing the Model}

In this phase, depending on the authentic leadership behaviors and school culture, models acceptable in terms of statistical fitness were obtained which were formed in independent conditions and which define the relationships of variables in independent variables. First of all, based on the model supposed to be appropriate, the goodness of fit indices were determined. The goodness of fit indices used in the study included GFI, AGFI, RMSEA, $\chi^{2}, d f$ and $\chi^{2} / d f^{\prime}$ and the coefficient of $t$. As for the standard fit measurement valuesof these indices, the coefficient of GFI and AGFI ranged between 0 and 1 . Though there is no full consensusin related literature, a coefficient calculated as over 0.85 (Anderson \& Gerbing, 1984; Cole, 1987; Marsh, Balla \& McDonald, 1988) or over 0.90 (Kline, 2005; Schumacker \& Lomax, 1996) is considered to be a good fit. The values obtained via RMSEA ranged between 0 and 1 . In contrast with GFI and AGFI, a value close to 0 obtained in RMSEA, which gives the error between the observed and produced matrices, is necessary for goodness of fit. Values of 0.05 or lower obtained via RMSEA are enough for goodness of fit. As for the ratio of $\chi^{2} / d f^{\prime}$, if it is between 2 and 5 , then there is goodness of fit; and values lower than 2 demonstrate excellent fit (Joreskog $\&$ Sörbom, 2001). If the value of $t$ is higher than 2 , then the goodness of fit index is statistically significant. In addition, the variables had a statistical 
relationship with the structures determined. Thus, the relationships between the constructs and variables in the model formed were confirmed.

\section{Results}

In this study, in order to determine the relationship between authentic leadership and school culture, a theoretical model based on the structural equation model was formed: the effect of the authentic leadership behaviors of school principals on school culture. Before testing the theoretical model formed, correlation and regression analyses were conducted to determine the linear relationships between the variables. Following this, the goodness of fit indices regarding the theoretical models was calculated to determine the consistencies of the models as well as the effects of the variables.

\section{Correlation Coefficients Regarding the Theoretical Model}

Table 2 presents the means and standard deviations regarding the research variables and the correlation coefficients in-between. When the teachers' mean scores regarding their perceptions of the authentic leadership behaviors of the school principals were examined, it was seen that the highest mean score belonged to the factor of transparency in relations $[X=3.33, S D=.62]$ and the lowest mean score to the factor of balanced processing $[X=3.08, S D=.71]$. When the teachers' perceptions of school culture were taken into account, the highest mean score belonged to the factor of $\operatorname{aim}[X=3.38, S D=.54]$. When the correlation coefficients were examined, it was found out that there was a positive relationship between the factors of authentic leadership and school culture and that the correlation coefficients ranged between .49 and .84 . 
Table 2. Correlation Matrix between Authentic Leadership and School Culture

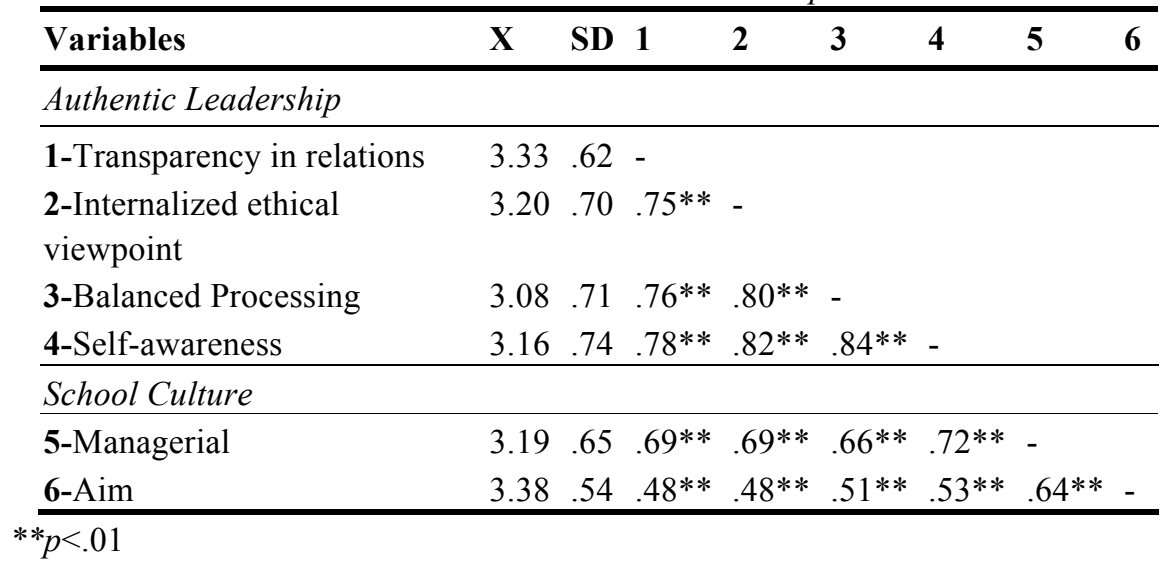

\section{Multiple Regression Coefficients Regarding the Theoretical Model}

Table 3 presents the results of the multiple regression analysis conducted to determine the extent to which the authentic leadership behaviors of school principals predicted the teachers' perceptions of school culture. It was seen that the variable of authentic leadership and the independent variables representing the factors of transparency in relations, internalized ethical viewpoint, balanced processing and self-awareness predict school culture positively; that these independent variables explained $53 \%$ of the change in school culture $\left[R=.728, R^{2}=.53, F=70.919, p<.01\right]$; and that $47 \%$ of school culture was explained by the other variables. As for the order of importance of the predictor variables on the dependent variable, it was self-awareness, transparency in relations, internalized ethical viewpoint and balanced processing, respectively. The variables of self-awareness and transparency in relations were significant predictors of school culture, while the other independent variables were not significant predictors of school culture. 
Table 3. Multiple Regression Matrix between Authentic Leadership and School Culture

\begin{tabular}{lllllll}
\hline Authentic Leadership & $\boldsymbol{B}$ & $\boldsymbol{S} \boldsymbol{H}_{\boldsymbol{B}}$ & $\boldsymbol{\beta}$ & $\boldsymbol{t}$ & $\boldsymbol{p}$ & VIF \\
\hline Constant & 1.23 & .13 & & 9.15 & .00 & \\
1- Transparency in relations & .19 & .06 & .21 & 2.80 & .00 & 3.01 \\
2- Internalized ethical & .11 & .06 & .14 & 1.71 & .08 & 3.66 \\
viewpoint & & & & & & \\
3- Balanced processing & .07 & .07 & .09 & 1.02 & .30 & 4.23 \\
4- Self-awareness & .25 & .07 & .34 & 3.66 & .00 & 4.67 \\
\hline Eigenvalue $_{\max / \min :} 706, R=.728, R^{2}=.531, F=70.919, p<.01$ \\
\hline
\end{tabular}

\section{Parameter Predictions and Goodness of Fit Indices}

Figure 2 illustrates an independent acceptable structural equation model which was obtained after the theoretical model was formed and which reflected the relationship between authentic leadership and school culture. In addition, the parameter predictions for the finalized model are also presented in Figure 2.

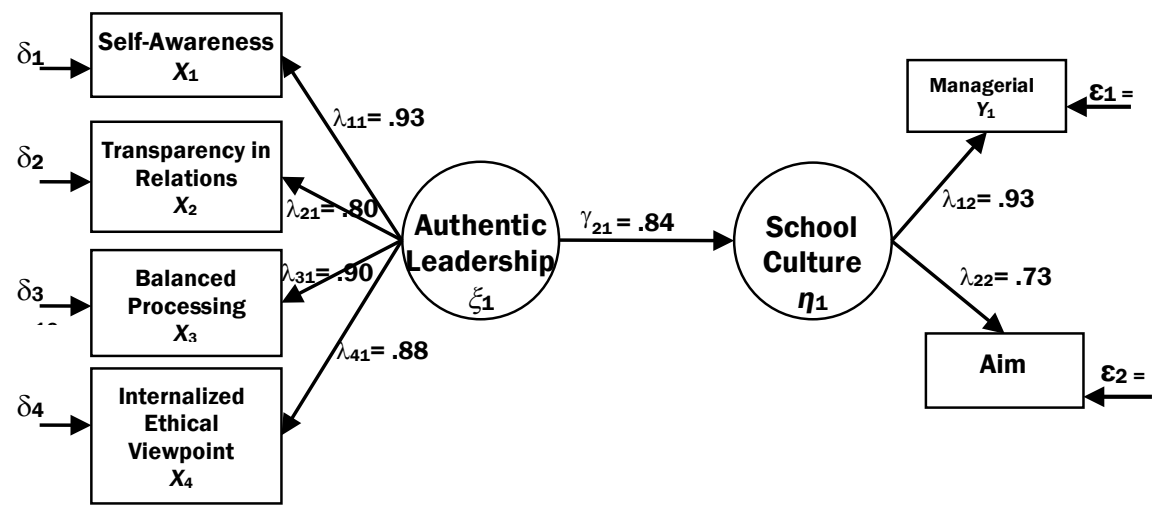

Figure 2. Structural Equation Diagram Model for Authentic Leadership and School Culture

Table 4 presents the goodness of fit indices regarding the simultaneous contribution of each observed and latent variable to the whole model for the theoretical models formed for the causal relationships. 
The goodness of fit for the theoretical model developed was determined with RMSEA, $\chi^{2}$ and $\chi^{2} / d f$, GFI, AGFI, CFI, NFI. RMSEA included the mean of the covariance and variance that was not explained by the model, and in the study, the RMSEA value was found to be .06, which was enough for goodness of fit (MacCallum et al., 1996). The arrows showing the variance which was not explained for each latent variable - in other words, the parameters regarding the errors - were included in the structural model. The variance explained for each latent variable in the model can be determined thanks to its relationship with the other latent variables. Therefore, the variance explained for each latent variable and thus the variance which was not explained accordingly - that is the error values can be regarded as a part of the structural model rather than of the measurement model. In the study, the ratio of $\chi^{2} / d f$ was calculated as 0.92 . This ratio demonstrates an indicator of goodness of fit between the observed and increased covariance matrices (Hair et al., 2006; Jöreskog \& Sörbom, 2001). In addition, GFI indicates both the relational degree of the covariance and the variance explained collectively by the model. In the study, the GFI value was calculated as .99, and the AGFI goodness of fit value was calculated as .98 similar to GFI. This result also demonstrates that the theoretical models of GFI and AGFI goodness of fit values were appropriate to the data collected (Hoyle \& Panter, 1995; Kline, 2005; Schumacker \& Lomax, 1996).

Table 4. Fit Parameters Regarding the Structural Equation Model

\begin{tabular}{ll}
\hline Fit Parameters & Coefficient \\
\hline GFI & .99 \\
AGFI & 098 \\
RMSEA & 006 \\
$d f$ & 8 \\
$\chi^{2}$ & 7.36 \\
$\chi^{2} / d f$ & .92 \\
\hline
\end{tabular}




\section{Multiple Correlation and Consistency Coefficients for the Measurement Models}

Table 5 presents the multiple correlation and consistency coefficients for the measurement models found in the theoretical model in the study. The multiple correlation coefficients demonstrates how well the observed variables measure the structures individually and collectively. For measurement models, multiple correlation coefficients are considered to be the reliability of observed variables for the measurement of latent variables. In the structural equation model, multiple correlation coefficients demonstrate the variance ratio of external variables on/above internal variable (Pang, 1996). Parallel to this, the multiple correlation coefficients between the components of the theoretical model obtained in the study ranged between 0.53 and 0.87 . The multiple correlation coefficients obtained for the observed variables were generally higher than the mean. This situation means that none of the observed variables found in the theoretical model was a latent variable. In addition, demonstrating that the observed variables obtained in the study were able to measure the theoretical model, the consistency coefficients of the measurement component were found to be at a reliable level of 0.92 and 0.90 .

The first measurement model in the study was authentic leadership. The multiple correlation coefficients for the observed variables were $0.86,0.64$, 0.81 and 0.71 for the factors of self-awareness, transparency in relations, balanced processing and internalized ethical viewpoint, respectively. Among these four observed variables, self-awareness was the most important and reliable variable to determine authentic leadership. Also, the consistency total coefficient for the theoretical model was at a reliable level of 0.92 .

The second measurement model was school culture. The multiple correlation coefficients regarding the observed variables were 0.86 and 0.53 for the factors of managerial and aim, respectively. Of these two observed variables, the factor of managerial was the most important and reliable variable to determine school culture. In addition, the consistency total correlation for the theoretical model was at a reliable level of 0.87 . 
Table 5. Multiple Correlation and Consistency Coefficients for the Structural Equation Model

\section{Fit Parameter}

Authentic Leadership

$X_{1}$ Self-awareness

$X_{2}$ Transparency in relations

$X_{3}$ Balanced processing

$X_{4}$ Internalized ethical viewpoint

$X_{\mathrm{s}}$ Consistency level

School Culture

$Y_{1}$ Managerial

$Y_{2}$ Aim

$Y_{\mathrm{s} 1}$ Consistency level

Authentic Leadership* School Culture $\eta$

\section{Coefficient} .86

.92

0.86

0.53

0.87

0.90

\section{Relationship between Authentic Leadership and School Culture}

Table 6 presents the correlation coefficients between the latent variables as a part of the results of the structural equation model. The findings obtained demonstrated that authentic leadership had a positive relationship with school culture $[r=.75]$.

Table 6. Correlation Matrix between Authentic Leadership and School Culture

\begin{tabular}{lll}
\hline Variables & $\mathbf{1}$ & $\mathbf{2}$ \\
\hline 1-Authentic Leadership & - & \\
2-School Culture & $.75^{*}$ & - \\
\hline$n=256, * p<.01$ & &
\end{tabular}

Table 7 and Figure 2 present the standardized regression matrix between authentic leadership and school culture. In the third part of the structural equation model formed to determine the effect of authentic leadership on school culture, authentic leadership had positive effect on school culture $\left(\gamma_{21}=.84\right)$. 
Table 7. Standardized Regression Matrix between Authentic Leadership and School Culture

\begin{tabular}{lll}
\hline Variables & $\mathbf{1}$ & $\mathbf{2}$ \\
\hline 1-Authentic Leadership & - & \\
2-School Culture & $.84 *$ & - \\
\hline
\end{tabular}

$n=256,{ }^{*} p<.01$

\section{Discussion}

The process of change experienced in leadership, which has an important role in organizations' achievement of their goals, has resulted in new expectations and caused organizations to find new ways to meet their changing needs. In this respect, new leadership approaches appropriate to current conditions have appeared. One of such new leadership approaches which has been on the agenda in recent years is authentic leadership. The number of studies on authentic leadership, which is a fairly new concept in related literature, is gradually increasing (Azanza, Moriano \& Molero, 2013; George, 2003; Kesken \& Ayylldı, 2008; Cooper, Scandura \& Schriesheim, 2005). The purpose of the present study carried out parallel to this increasing number of other similar studies was to determine the effects of authentic leadership behaviors of school principals on school culture. In line with this purpose, in the study, a theoretical model was formed on the basis of the structural equation model. In this theoretical model formed, authentic leadership was taken as the independent variable, and school culture was taken as the dependent variable.

The structural equation model analysis conducted in the study revealed that the goodness of fit indices regarding the model formed was at a sufficient level. This result demonstrated that the authentic leadership and school culture model could be established. The findings obtained in other studies which revealed a relationship between leadership and school culture (Kythreotis, Pashiardis, \& Kyriakides, 2010; Veiseh, Mohammadi, Pirzadian, \& Sharafi, 2014; Wang \& Zepeda, 2013) and which reported that leadership was one of the important predictors of school culture support the fact that the model obtained in the present study could be formed.

The theoretical model of the study was made up of three parts: two measurement components and one structural equation component. The 
findings obtained regarding the measurement models could be summarized as follows;

- Authentic leadership, the external variable in the study, included not only such leadership behaviors as those which think consciously about the thinking processes, which are aware of the value judgments of other people and which give importance to ethical values (Avolio et al., 2004) but also four observed variables [self-awareness, transparency in relations, balanced processing and internalized ethical viewpoint]. The first measurement model in the study provided several clues regarding the authentic leadership behaviors of school principals. The self-awareness factor of authentic leadership is the most important and most reliable variable to determine authentic leadership.

- School culture, the internal variable in the study, is generally defined as the common values, beliefs and meanings shared by school members (Şişman, 2007) and made up of two observed variables [managerial and aim]. Of these two observed variables, the factor of managerial is the most important and most reliable variable to determine school culture.

- In both measurement models, the consistency total coefficient was at a reliable level for the theoretical model.

The structural equation components in the study were as follows: ( $i$ ) effect of authentic leadership on school culture. The findings regarding the structural equation component could be summarized as;

- As school principals' behaviors of self-awareness, transparency in relations, balanced processing and internalized ethical viewpoint increase, teachers' perceptions of school culture increase as well.

- School principals' behaviors of self-awareness, transparency in relations, balanced processing and internalized ethical viewpoint cause teachers to develop positive perceptions regarding the dimensions of managerial and aim, which were the school culture variables.

- Authentic leadership was found to have strong positive effect on school culture.

In studies conducted, authentic leadership was found to have a relationship with such outcomes as identification with the school principal (Walumbwa et al., 2010), personal identity (Wong et al., 2010), confidence 
in the leader (Clap-Smith, Vogelgesang \& Avey, 2009; Wong et al., 2010), job satisfaction (Jensen \& Luthans, 2006, Walumbwa et al., 2008), organizational dedication (Jensen \& Luthans, 2006; Walumbwa et al., 2008), work happiness (Jensen \& Luthans, 2006), employeecommitment (Jensen \& Luthans, 2006; Walumbwa et al., 2008) and job performance (Walumbwa et al., 2008). However, in related literature, there is no research conducted to examine the relationship between authentic leadership and school culture. In the present study carried out within the context of teachers' perceptions, a positive relationship was found between the authentic leadership behaviors of school principals and school culture. In addition, authentic leadership was an important predictor of school culture. Considering all these results as well as the relationship of authentic leadership with the positive climate and conditions at school, it could be stated that authentic leadership is influential on school culture. The reason is that school principals' positive emotions reflect upon teachers via social interactions and help establish a positive school culture (Kernis, 2003; Kesken \& Ayyıldız, 2008). Also, today, authentic leadership that has appeared with the increasing need for leaders who are honest themselves and who have self-consciousness is one of positive and constructive leadership types such as ethical leadership which focused on meaning, spiritual leadership and servant leadership. The results obtained in the study are consistent with those of other studies in related literature which revealed a relationship between leadership types and school culture and which reported that leadership has an important role in school culture (Avolio \& Bass, 2002; Schein, 1985; Yalçın \& Karadağ, 2013; Yörük \& Sağban, 2012).

To sum up, in the study, based on the teachers' perceptions, it could be stated that school culture is made up of two factors: managerial and aim. The findings obtained demonstrate that behaviors regarding transparency in relations and self-awareness have effect on school culture. However, the structural equation model formed explained only $53 \%$ of the total variance regarding the relationship between authentic leadership and school culture. This result requires future research to be conducted to define new variables more in number related to authentic leadership and school culture perception with a structural equation model to be formed. In addition, the number of the participants in the present study was around 250, and future studies could be conducted with larger sizes of samples. Lastly, it should be 
remembered that the results of a structural equation model is always limited to the variables and factors determined within the model content.

The survey data were collected from only one city center in Turkey, the generalizability of the results is limited. Additionally, the data in this study were collected via self-report, which might have caused subjectivity and biases in the relationships between the variables. The most important methodological limitation of this research is common method bias. The main reason for this limitation was the collection of the research data from a single source (teachers), which may have led to artificial increases in the observed correlations. Although it was not possible to fully eliminate the mentioned limitations of this research, we sought to minimize the error level. Therefore, the necessary measures, within the scope of the research, were taken during the data collection phase. First, the validity and reliability of the scale used for the data collection phase of the study were tested. Second, during the face-to-face interviews, it was clearly expressed that the responses would kept completely confidential and would not be revealed in any way. Additionally the questionnaire was designed in a manner such that the scale items related to independent variables came before the items related to dependent variables.

\section{References}

Alig-Mielcarek, J. M. (2003). A model of school success: Instructional leadership, academic press, and student achievement (Doctoral dissertation, The Ohio State University).

Alvesson, M. (1993). Cultural perspectives on organizations. Cambridge: Cambridge University Press.

Anderson, J. C., \& Gerbing, D. (1984). The effect of sampling error on convergence, improper solutions, and goodness-of-fit indices for maximum likelihood confirmatory factor analysis. Psychometrika, 49, 155-173.

Arlı, D. (2011). Öğretmenlerin örgütsel vatandaşlık davranışlarının örgüt kültürü algıları ve örgütselgüven düzeyleri açısından incelenmesi (Yayınlanmamış doktora tezi). Ege Üniversitesi, İzmir.

Avolio, B. (1999). Full Leadership Development: Building the Vital Forces in Organization. Thousand Oaks: Sage. 
Avolio, B. J., \& Bass, B. M. (2002). Manual for the multifactor leadership questionnaire (Form 5X). Redwood City, CA: Mindgarden.

Avolio, B., Luthans, F., \& Walumbwa, F.O. (2004). Authentic leadership: Theory-building for veritable sustained performance. Lincoln: Gallup Leadership Institute, University of Nebraska.

Avolio, B. J., Gardner, W. L., Walumbwa, F. O., Luthans, F., \& May, D. R. (2004). Unlocking the mask: A look at the process by which authentic leaders impact follower attitudes and behaviors. The Leadership Quarterly, 15(6), 801-823.

Avolio, B. J., \& Gardner, W. L. (2005). Authentic leadership development: Getting to the root of positive forms of leadership. The Leadership Quarterly, 16, 315-338.

Azanza, G., Moriano, J. A., \& Molero, F. (2013). Authentic leadership and organizational culture as drivers of employees' job satisfaction. Journal of Work and Organizational Psychology, 29(2), 45-50.

Barr, J. J. (2011). The relationship between teachers' empathy and perceptions of school culture. Educational Studies, 37(3), 365-369. doi:10.1080/03055698.2010.506342

Barrett, P. (2007). Structural equation modelling: Adjudging model fit. Personality and Individual differences, 42(5), 815-824.

Bass, B. M. (1990). Bass and Stogdill's handbook of leadership: theory, research \& managerial applications. NY: Free Pres.

Bass, B. M., \& Steidlmeier, P. (1999). Ethics, character, and authentic transformational leadership behavior. The Leadership Quarterly, 10(2), 181-217.

Baumeister, R. F. (1987). How the self-became a problem: A psychological review of historical research. Journal of personality and social psychology, 52(1), 163.

Begley, P. T. (2001). In pursuit of authentic school leadership practices. International Journal of Leadership in Education, 4, 353-365.

Bhindi, N., \& Duignan, P. (1997). Leadership for a new century authenticity, intentionality, spirituality and sensibility. Educational Management Administration \& Leadership, 25(2), 117-132.

Blake, R. R., \& Mouton, J. S. (1964). The managerial grid. Houston, TX: Gulf.

Bolman, L. \& Deal, T. (2003). Reframing organizations: Artistry, choice and leadership. San Francisco, CA: Jossey-Bass. 
Bolton, D. A. (2011). The relationship between principals' transformational leadership behaviors and school culture (Unpublished master thesis). Widener Unversity.

Canizo, T. L. (2002). Establishing collaborative structures and relationships: Teacher leaders' experiences. Unpublished doctoral dissertation, The University of Arizona, Arizona.

Chan, A. Y. L. H., Hannah, S. T., \& Gardner, W. L. (2005). Veritable authentic leadership: Emergence, functioning, and impacts. Authentic leadership theory and practice: Origins, effects and development, 3, 3-41.

Clapp-Smith, R., Vogelgesang, G. R., \& Avey, J. B. (2009). Authentic leadership and positive psychological capital the mediating role of trust at the group level of analysis. Journal of Leadership \& Organizational Studies, 15(3), 227-240.

Cole, D. A. (1987). Utility of confirmatory factor analysis in test validation research. Journal of Consulting and Clinical Psychology, 55, 10191031.

Cooper, C. D., Scandura, T. A., \& Schriesheim, C. A. (2005). Looking forward but learning from our past: Potential challenges to developing authentic leadership theory and authentic leaders. The Leadership Quarterly,16(3), 475-493.

Çelik, V. (2002). Okul kültürü ve yönetimi. Ankara: Pegem A.

Çelikten, M. (2003). Okul kültürünün şekillendirilmesinde müdürün rolleri.Türk Ĕgitim Bilimleri Dergisi, 1(4).

Deal, T. E., \& Peterson, K. D. (1999). Shaping school culture: The heart of leadership. San Francisco, CA: Jossey Bass.

Demirtaş, Z. (2010). Okul kültürü ile öğrenci başarısı arasındaki ilişki. Ĕgitim ve Bilim, 35(158).

Fiedler, F. E. (1967). A theory of leadership eff ectiveness. New York, NY: McGraw-Hill.

Gardner, W. L., Avolio, B. J., Luthans, F., May, D. R., \& Walumbwa, F. O. (2005). "Can you see the real me?" A self-based model of authentic leader and follower development. The Leadership Quarterly, 16, 343-372.

Gardner, W. L., Cogliser, C. C., Davis, K. M., \& Dickens, M. P. (2011). Authentic leadership: A review of the literature and research agenda. The Leadership Quarterly, 22(6), 1120-1145.

George, W. (2003). Authentic leadership: Rediscovering the secrets to 
creating lasting value. San Francisco: Jossey-Bass.

George, W., \& Sims, P. (2007). True north: Discover your authentic leadership. San Francisco: Jossey-Bass.

Goldman, B. M., \& Kernis, M. H. (2002). The role of authenticity in healthy functioning and subjective well-being. Annals of the American Psychotherapy Association, 5(6), 18-20.

Gruenert, S. (2005). Correlations of collaborative school cultures with student achievement. NASSP Bulletin, 89, 43- 55. doi: 10.1177/019263650508964504

Hair, J.F., Black, W.C., Babin, B.J., \& Anderson, R.E. (2010). Multivariate data analysis. Prentice Hall, Upper Saddle River, New Jersey.

Hamilton, M.L., \& Richardson, V. (1995). Effects of the culture in two schools on the process and outcomes of staff development. The Elementary School Journal, 95, 367-382.

Harris, A. (2002). School improvement: What's in it for schools? New York: Roadledge Falmer.

Harter, S. (2002). Authenticity. In C. S. Snyder, \& S. J. Lopez (Eds.), Handbook of positive psychology (pp. 382-394). Oxford: Oxford University Press.

Hatchett, D. Y. (2010). The impact of school culture, teacher job satisfaction, and student attendance rates on academic achievement of middle school students (Unpublished doctoral dissertation). University of Louisville.

Herndon, B. C. (2007). An analysis of the relationships between servant leadership, school culture, and student achievement (Unpublished doctoral dissertation). University of Missouri, Columbia.

Hofstede, G. (1998). Attitudes, values and organizational culture: Disentangling the concepts. Organization Studies, 19(3), 477-492. doi: 10.1177/017084069801900305

Hooper, D., Coughlan, J., \& Mullen, M. (2008). Structural equation modelling: Guidelines for determining model fit. Articles, 2.

Horn-Hasley, K. (2007). An examination of school culture and student engagement in a test-focused age of accountability. Unpublished doctoral dissertation, Texas A \& M University, US.

Hoy, W. K., \& Miskel, C. G. (2012). Eğitim yönetimi: Teori, araştırma ve uygulama. (Çev. Ed. S. Turan). Ankara: Nobel.

Hoyle, R. H., \& Panter, A. T. (1995). Writing about structural equation models. In R. H. Hoyle (Ed.), Structural equation modeling (pp. 
158-176). Thousand Oaks, CA: Sage.

Jensen, S. M., \& Luthans, F. (2006). The relationship between entrpreneurs psychological capital and authentic leadership dimensions. Journal of Managerial Issues, 18(2), 254-273.

Jöreskog, K., \& Sörbom, D. (2001). LISREL 8.51. Mooresvile: Scientific Software.

Karadağ, E. (2009). Spiritual leadership and organizational culture: A study of structural equation model. Educational Sciences: Theory \& Practice, 9(3), 1357-1405.

Karadağ, E., Kılıçoğlu, G., \& Yılmaz, D. (2014). Organizational cynicism, school culture, and academic achievement: The study of structural equation modeling. Educational Sciences: Theory \& Practice, 14(1), 102-113.

Karpicke, H. \& Murphy M. E. (1996). Productive school culture: Principals working from the inside, NASSP Bulletin, 80, 26-35.

Keedy, J. L. \& Achilles, C. M. (1997). The need for school-constructed theories in practice in U. S. school restructuring. Journal of Educational Administration, 35, 102-121.

Kernis, M. H., \& Goldman, B. M. (2006). A multicomponent conceptualization of authenticity: Theory and research. In M. P. Zanna (Ed.), Advances in experimental social psychology ( pp. 283357). San Diego: Academic Press.

Kesken, J., \& Ayyildiz, N. A. (2008). Liderlik yaklasimlarinda yeni perspektifler: pozitif ve otantik liderlik. Ege Academic Review, 8(2), 729-754.

Kline, R. B. (2005). Principle and practice of structural equation modeling. New York, NY: Guilford.

Kotter, J. P. (1990). General managers. NY: Simon and Schuster.

Kotter, J. P., \& Heskett, J. L. (1992). Corporate culture and performance. New York: Hardcover

Kouzes, J., \& Posner, B. (2002). The leadership challenge. San Fransisco, CA: Jossey-Bass.

Kythreotis, A., Pashiardis, P., \& Kyriakides, L. (2010). The influence of school leadership styles and culture on students' achievement in Cyprus primary schools. Journal of Educational Administration, 48(2), 218-240.

Lambert, L. G. (1988). Building school culture: an open letter to principals, NASSP Bulletin, 72, 54-62. 
Law, W. W. (2013). Culture, gender and school leadership: school leaders' self-perceptions in China. Compare: A Journal of Comparative and International Education, 43(3), 295-322.

Lima, N. E. (2006). A case study on principal behaviors cultivating a positive school culture in an elementary school. Unpublished doctoral dissertation, Johnson \& Wales University, Rode Island.

Lorraine, R. R. D. O. (2011). A study of the relationship between teachers' perception of principal's leadership practices and school culture to student achievement (Order No. 3482494). Available from ProQuest Dissertations \& Theses Global. (910555172).

Lucas, S. E. (2001). Transformational leadership: Principals, leadership teams, and school culture (Order No. 3013000). Available from ProQuest Central; ProQuest Dissertations \& Theses Global. (250165729).

Lunenburg, F., \& Ornstein, A. (2011). Educational administration: Concepts and practices. Cengage Learning.

Luthans, F. (2003). Positive organizational behavior (POB): Implications for leadership and HR development and motivation. Motivation and Leadership at Work, 178-195.

Luthans, F., \& Avolio, B. (2003). Authentic leadership development. Positive organizational scholarship, 241, 258.

Luthans, F., Avolio, B. J., Avey, J. B., \& Norman, S. M. (2007). Positive psychological capital: Measurement and relationship with performance and satisfaction. Personnel Psychology, 60(3), 541572.

MacCallum, R.C., Browne, M.W., and Sugawara, H., M. (1996). Power analysis and determination of sample size for covariance structure modeling, Psychological Methods, 1(2), 130-49.

Marsh, H. W., Balla, JR., \& McDonald, R. P. (1988). Goodness-of-fit indexes in confir-matory factory analysis: The effects of sample size. Psychological Bulletin, 103(3), 391-410.

McGregor, D. (1960). The human side of enterprise. New York, NY: McGraw-Hill Book.

McMillan, J. H., \& Schumacher, S. (2006). Research in education: Evidence based inquiry. Boston, MA: Brown and Company.

Mees, G. W. (2008). The relationship among principal's leadership, school culture, and student achievement in Missouri middle schools. (unpublished doctoral dissertation). 
Miles, M. T. (2002). The relative impact of principal instructional and transformational leadership on school culture (Unpublished doctoral dissertation). The University of Missouri, Columbia, US.

Neuman, W. L. (2007). Social research methods: Quantitative and qualitative approaches. Boston: Allyn and Bacon.

Pang, N. S. K. (1996). School values and teachers' feelings: A LISREL model. Journal of Educational Administration, 34(2), 64-83.

Pawlas, E.G. (1997). Vision and school culture. NASSP Bulletin, 81(587), 118-128.

Peterson, K. D., \& Brietzke, R. (1994). Building collaborative cultures: Seeking ways to reshape urban schools. Urban Education Monograph Series, Oak Brook, IL: North Central Regional Educational Laboratory.

Peterson, K. D. \& Deal, T. E. (2002). Shaping school culture: Fieldbook. San Francisco: Jossey-Bass.

Reddin, W. J. (1970). Effective management by objectives the 3D method of MBO. USA: McGraw-Hill.

Schein, E. H. (1985). Defining organizational culture. Classics of organization theory, 3, 490-502.

Schein, E.H. (1992). Organizational culture and leadership. San Francisco: Jossey-Bass.

Schooley, M. L. (2005). An analysis of the relationship between transformational leadership and school culture (Order No. 3235157). Available from ProQuest Dissertations \& Theses Global. (305450380).

Schumacker, R. E., \& Lomax, R. G. (1996). A beginner's guide to structural equation modeling. Hilsdale, NJ: Erlbaum.

Senge, P. M. (1990). The fifth discipline: The art and practice of the learning organization. New York: Doubleday/Currency.

Sergiovanni, T.J. (2006). The principalship: A reflective practice perspective. Massachusetts: Allyn\& Bacon.

Stogdill, R. (1948). Personal factors associated with leadership: A survey of the literature. Journal of Psychology, 25, 35-71.

Stolp, S., \& Smith, S. (1995). Transforming school culture: Stories, symbols, values and the leader's role. ERIC Clearinghouse on Education Management, USA: University of Oregon.

Şahin, S. (2004). Okul müdürü ve öğretmenler ile okulun bazı özellikleri açısından okul kültürü üzerine bir değerlendirme. Kuram ve 
Uygulamada Ĕ̌itim Yönetimi, 10 (39), 458-474.

Şahin, S. (2011). The relationship between instructional leadership style and school culture (Izmir Case). Educational Sciences: Theory \& Practice, 11(3), 1920-1927.

Şirin, E. (2011). Illköğretim okullarındaki öğretmenlerin okul kültürü algıları ile örgütsel sinizm tutumları arasındaki ilişki (Yayımlanmamış yüksek lisans tezi). Yeditepe Üniversitesi, İstanbul.

Şişman, M. (2002). Ë̆itimde mükemmellik arayışı: Etkili okullar. Ankara: Pegem A.

Şişman, M. (2007). Eğitimde mükemmellik arayışı: Etkili okullar. Ankara: Pegem A.

Tabak, A., Polat, M., Coşar, S., Türköz, T., \& Ölçeği, O. L. (2012). Otantik liderlik ölçeği: Geçerlilik ve güvenilirlik çalışması. İ̧, Güç Endüstri İlişkileri ve İnsan Kaynakları Dergisi, 14(4), 89-106.

Tanrıverdi, S. (2007). Katılımcı okul kültürünün yabancı dil ögretmenlerinin iş motivasyonuyla ilişkisine yönelik örnek bir çalışma (Yayımlanmamış yüksek lisans tezi). Yeditepe Üniversitesi, İstanbul.

Troutman, L. D. (2012). The impact of principal leadership on school culture and student achievement (Unpublished doctoral dissertation). Wingate University.

Turan, S., \& Bektas, F. (2013). The relationship between school culture and leadership practices. Eurasian Journal of Educational Research, 52, 155-168.

Valentine, J. (2001). Frameworks for continuous school improvement: A synthesis of essential concepts. Middle Level Leadership Center publications (MU).

Veiseh, S., Mohammadi, E., Pirzadian, M., Sharafi, M. (2014). The relationship between transformational leadership and organizational culture. Journal of Business Studies Quarterly, 5(3), 11-124.

Wang, F., \& Zepeda, S. J. (2013). A comparative study of two schools: How school cultures interplay the development of teacher leadership in Mainland China. Creative Education, 4(09), 63.

Walumbwa, F. O., Avolio, B. J., Gardner, W. L., Wernsing, T. S., \& Peterson, S. J. (2008). Authentic leadership: Development and validation of a theory-based measure. Journal of Management, 34(1), 89-126.

Walumbwa, F. O., Wang, P., Wang, H., Schaubroeck, J., \& Avolio, B. J. 
(2010). Retracted: Psychological processes linking authentic leadership to follower behaviors. The Leadership Quarterly, 21(5), 901-914.

Williams, T. H. (1989). Structural equation models. In J. P. Keeves (Ed.), Educational research, methodology, and measurement: An international handbook (pp. 767-874), Oxford:Pergamon.

Wong, C. A., \& Cummings, G. G. (2009). The influence of authentic leadership behaviors on trust and work outcomes of health care staff.Journal of Leadership Studies, 3(2), 6-23.

Wong, C. A., Spence-Laschinger, H. K., \& Cummings, G. G. (2010). Authentic leadership and nurses' voice behaviour and perceptions of care quality. Journal of Nursing Management, 18(8), 889-900.

Yalçın, M., Karadağ, E. (2013). Hizmetkar liderlik ve okul kültürü: Bir yapısal eşitlik modellemesi. Inönü Üniversitesi Eğitim Fakültesi Dergisi, 14(2).

Yau Ho P., W. (2010). Kindergarten teachers' perceived school culture and well-being: a comparison of non-profit-making and profit-making kindergartens. Early Child Development \& Care, 180(3), 271-278. doi:10.1080/03004430701769019

Yüksel, F. (2009). Ortaögrretim kurumlarında örgüt kültürü ile örgütsel güven arasındaki ilişki (Yayımlanmamış yüksek lisans tezi). Maltepe Üniversitesi, İstanbul. 
Engin Karadag is a professor in the Department of Educational Leadership \& Policy Analysis at the Akdeniz University.

Ozge Oztekin-Bayir is a research assistan in the Department of Educational Leadership \& Policy Analysis at the Akdeniz University.

Note: This work was supported by the GEBIP Award of the Turkish Academy of Sciences.

Address: Akdeniz University, Education Faculty, Kampus, Antalya, Turkey

Email: engin.karadag@hotmail.com 